\title{
PHYSIOLOGICAL AND STRUCTURAL MODIFICATIONS IN SNAIL MEDIC (MEDICAGO SCUTELLATA L.) PLANTS EXPOSED TO SALINITY
}

\author{
Houneida Attia, ${ }^{1,2} *$ K. H. Alamer, ${ }^{2}$ Imen Selmi, ${ }^{1}$ W. DJebali, ${ }^{1}$ \\ Wided ChaÏBI ${ }^{1}$ and MouHiba Ben NASRI ${ }^{1}$ \\ ${ }^{1}$ Physiology and Biochemistry of Plant Response to Abiotic Stress, Faculty of Science of Tunis, Tunis \\ El Manar University, 2092 Tunis, Tunisia \\ ${ }^{2}$ Biology Department, Faculty of Science, Taif University, Kingdom of Saudi Arabia
}

(Received: December 4, 2017; accepted: April 19, 2018)

\begin{abstract}
Seeds of snail medic (Medicago scutellata L.) were assessed for their response to salt at the germination and seedling stages. $\mathrm{NaCl}$ at concentrations 86 and $170 \mathrm{mM}$ decreased the final germination percentage. Embryonic axis length, water content and dry weight of embryonic axis and cotyledons were also reduced by salt treatment. Furthermore, 28-d-old plants were grown hydroponically with different $\mathrm{NaCl}$ concentrations $(0,86$ and $170 \mathrm{mM})$. After 7 days of treatment, growth, water content and development of the different organs of $M$. scutellata plant were affected especially at the highest $\mathrm{NaCl}$ concentration (170 $\mathrm{mM}$ ). However, $\mathrm{NaCl}$ did not affect root length and the number of stem shoots but reduced stem length and total leaf area. Salt treatment increased markedly the concentration of $\mathrm{Na}^{+}$in leaf and root tissues while reduced that of $\mathrm{K}^{+}$only in root and stem tissues. Lipid peroxidation revealed the damage of the membranes of roots and leaves. Moreover, showed a more intense suberization and lignification at the cambial zone of roots of $M$. scutellata, were observed under the effect of $\mathrm{NaCl}$.
\end{abstract}

Keywords: Salinity - anatomical changes - growth - mineral nutrition - Medicago scutellata

\section{INTRODUCTION}

Salinity is one of the major factors that affect plant growth in Tunisia, where there is a wide variety of saline-sodic soils in depressions and in the main sebkhas and chotts $[20,23,25]$. Moreover, in irrigated areas, the low quality of irrigation water charged with dissolved salts has resulted unfortunately in soil secondary salinization responsible for decline in productivity [25]. Legumes like most crop plants are susceptible to salinity $[7,10]$. These plants are widely grown for grain and forage purposes, their worldwide economic importance is only secondary for grasses [14]. In addition, legumes can establish root symbioses with nitrogen-fixing soil bacteria, enabling the plants to grow in nitrogen-poor soils. This ability to colonize soils where other plants cannot thrive makes the study of legumes and their symbioses important for agriculture.

Snail medic (Medicago scutellata) is a diploid annual forage legume cultivated in Mediterranean areas and Australia in order to improve pasturelands, and used in crop

\footnotetext{
*Corresponding author; e-mail address: houneida_attia@yahoo.fr
} 
rotation [28]. Annual medic species because of nitrogen fixation and proper quality of fodder have high crop values [12]. Together with M. truncatula and M. polymorpha, M. scutellata represents an important pasture legume for increasing forage production in marginal areas where the environmental conditions limit the growth of perennial species as M. sativa.

In this paper, we studied the response of $M$. scutellata to different $\mathrm{NaCl}$ concentrations during vegetative growth. Dry matter production of leaves, stems and roots, and ion accumulation were measured, along with chlorophyll contents. Electrolyte leakage and malondialdehyde (MDA) content were determined as proxies of oxidative stress, and we have especially studied the effect of $\mathrm{NaCl}$ on structural modifications, including suberization and lignification in M. scutellata.

\section{MATERIALS AND METHODS}

\section{Plant material and germination conditions}

The seeds of Medicago scutellata were provided by Seed Laboratory of the Tunisian Ministry of Agriculture. For germination, seeds were disinfected in oxygenated water for $20 \mathrm{~min}$ and rinsed in distilled water. The seeds were then placed in Petri dishes supplied with double layer filter paper initially moistened with a solution of the respective salt concentration: 0,86 and $170 \mathrm{mM}$ [20]. The seeds were then incubated for $9 \mathrm{~d}$ in darkness at room temperature $\left(25 \pm 1{ }^{\circ} \mathrm{C}\right)$. Each treatment was performed on 25 seeds per Petri dish and was replicated three times. Seeds with emerged radicle were counted daily. Final germination percentage (FG\%) was calculated as $100 \times$ number of germinated seeds divided by the number of sown seeds. After $9 \mathrm{~d}$, seedlings were divided into embryonic axis and cotyledons for determination of growth parameters. Fresh weights (FW) of all samples were recorded. Plant material was dried at $60{ }^{\circ} \mathrm{C}$ for 2 days and the dry weight (DW) was measured. Tissue water content was obtained from the (FW-DW/FW) ratio.

\section{Culture conditions}

Seeds of Medicago scutellata were disinfected in oxygenated water for $20 \mathrm{~min}$ and rinsed in distilled water and germinated at $25^{\circ} \mathrm{C}$ in Petri dishes on filter paper moistened with distilled water. Nine-d-old seedlings were transferred in pots containing $2 \mathrm{~L}$ of aerated, 2-fold diluted nutritive solution [16], with one plant per pot. The solution contained $0.50 \mathrm{mM} \mathrm{MgSO}_{4}, 0.25 \mathrm{mM} \mathrm{KH}_{2} \mathrm{PO}_{4}, 1.25 \mathrm{mM} \mathrm{Ca}\left(\mathrm{NO}_{3}\right)_{2}, 1.25 \mathrm{mM}$ $\mathrm{KNO}_{3}, 50 \mu \mathrm{M} \mathrm{KCl}, 1 \mu \mathrm{M} \mathrm{MnSO}_{4}, 0.5 \mu \mathrm{M} \mathrm{CuSO}_{4}, 0.5 \mu \mathrm{M} \mathrm{ZnSO}_{4}, 10 \mu \mathrm{M} \mathrm{H}_{3} \mathrm{BO}_{3}$, $0.05 \mu \mathrm{M}\left(\mathrm{NH}_{4}\right) \mathrm{Mo}_{7} \mathrm{O}_{24}$, and $1.5 \mu \mathrm{M}$ Fe-EDTA. It was renewed weekly. The photoperiod was $16 \mathrm{~h}$ with a photosynthetic photon flux density of $150 \mu \mathrm{mol} \mathrm{m}^{-2} \mathrm{~s}^{-1}$ at the plant level. The day/night temperature and relative humidity regimes were $25{ }^{\circ} \mathrm{C} / 18{ }^{\circ} \mathrm{C}$ and $60 / 80 \%$, respectively. 


\section{Plant morphology and growth}

Twenty-eight-day-old plants grown on control medium were exposed to different $(0$, 86 and $170 \mathrm{mM}) \mathrm{NaCl}$ treatments during 7 days. Five plants per treatment were sampled (final harvest) and roots, stems, and leaves were separated. Roots were gently surface dried. Shoot and root fresh weights were immediately determined. Morphological parameters (stem length, root length and leaf area) were measured using a scanner and Optimas ${ }^{\circledR}$ software and number of stem shoots was also determined by a simple counting. The samples were then oven-dried for $48 \mathrm{~h}$ at $70{ }^{\circ} \mathrm{C}$ and weighted.

\section{Ion accumulation}

At the final harvest, roots (but not other organs) were rinsed in $100 \mathrm{~mL}$ cold distilled water (three successive baths, $30 \mathrm{~s}$ each) then gently blotted between paper towels. Ions $\left(\mathrm{K}^{+}\right.$and $\left.\mathrm{Na}^{+}\right)$were extracted from $25 \mathrm{mg}$ samples of dried tissues with $0.5 \%$ (v/v) $\mathrm{HNO}_{3}$ for $48 \mathrm{~h}$, and assayed by flame photometer (Jenway PFP7, ELE Instrument Co. Ltd) using butane-air flame.

\section{Chlorophyll content}

For each treatment, four plants were used and treated individually. Whole set of fresh leaves of each plant was separately incubated in the dark for $72 \mathrm{~h}$ at $4{ }^{\circ} \mathrm{C}$ in acetone $80 \%(\mathrm{v} / \mathrm{v})$. Absorbance of acetone extracts was measured at 460, 645, and $663 \mathrm{~nm}$ with a DU 640 Beckman spectrophotometer. Concentrations of chlorophyll $a, b$, and total chlorophylls were calculated using the equations proposed by McKinney [22].

\section{Membrane permeability (electrolyte leakage, EL)}

Electrolyte leakage from leaf cells was determined as described by Dionisio-Sese and Tobita [9]. Leaf samples were taken and cut into $1 \mathrm{~cm}^{2}$ sections (approximately $200 \mathrm{mg} \mathrm{FW}$ ). The samples were then placed in individual stoppered vials containing $10 \mathrm{~mL}$ of distilled water. The tubes were incubated in a water bath at $32{ }^{\circ} \mathrm{C}$ for $2 \mathrm{~h}$ and the initial electrical conductivity of the medium (EC1) was measured using digital electrical conductivity meter (DDS-11A). The samples were autoclaved at $121{ }^{\circ} \mathrm{C}$ for $20 \mathrm{~min}$ to release the remaining electrolytes, then cooled to $25^{\circ} \mathrm{C}$, and the final electrical conductivity (EC2) was measured. The electrolyte leakage (EL) was calculated as $(\mathrm{EC} 1 / \mathrm{EC} 2) \times 100$. Six replicates from six different plants were used.

EL from roots was determined after the immersion of root in $0.5 \mathrm{mM} \mathrm{CaCl}_{2}$ solution for $5 \mathrm{~min}$ and incubation in darkness with $25 \mathrm{~mL}$ of water for $1 \mathrm{~h}$ (EC1 determi- 
nation). Roots were then transferred into $25 \mathrm{~mL}$ of boiling water for $5 \mathrm{~min}$, cooled to $25^{\circ} \mathrm{C}$ and the final electrical conductivity (EC2) was measured. EL was calculated according to Shalata and Neumann [32]: $\mathrm{EL}=(\mathrm{EC} 1 /(\mathrm{EC} 1+\mathrm{EC} 2)) \times 100$.

\section{Lipid peroxidation}

Lipid peroxidation was determined using the thiobarbituric acid (TBA) reaction to measure the tissue content of MDA [15]. An amount of $250 \mathrm{mg}$ of leaves, stems or roots were ground in a cold mortar using $50 \mathrm{mM}$ Tris- $\mathrm{HCl}(\mathrm{pH} 7.5)$ as buffer containing $0.2 \mathrm{mM}$ EDTA and $0.2 \%(\mathrm{v} / \mathrm{v})$ Triton X-100. The homogenate was centrifuged at $10,000 \times \mathrm{g}$ for $15 \mathrm{~min}$. $2.5 \mathrm{~mL}$ of $0.25 \%(\mathrm{w} / \mathrm{v})$ thiobarbituric acid containing $10 \%$ $(\mathrm{w} / \mathrm{v})$ trichloroacetic acid and $0.01 \%$ butylated hydroxytoluene was added to aliquots of supernatant. The mixture was heated at $95{ }^{\circ} \mathrm{C}$ for $15 \mathrm{~min}$ and then quickly cooled in an ice bath. After centrifugation at $5500 \mathrm{~g}$ for $5 \mathrm{~min}$, the absorbance of the supernatant was read at 535 and $600 \mathrm{~nm}$. The MDA content was calculated by using a molar extinction coefficient of $155 \mathrm{mM}^{-1} \mathrm{~cm}^{-1}$. Six different plants were used as replicates.

\section{Histology}

Histological observations were made on root, stem and leaf transverse sections in two ways. In the first case, sections were cut on a freezing microtome (Leitz Kryomat 1700 ), and placed in sodium hypochlorite $\left(12^{\circ}\right)$ for 10 to $20 \mathrm{~min}$ to remove the cell contents. After treatment with acetic acid $30 \%(\mathrm{v} / \mathrm{v})$ for $5 \mathrm{~min}$, the sections were stained with a mixture of alum carmine and methyl-green. In the second case, the leaf sections were fixed in a mixture of alcohol and acetic acid for $24 \mathrm{~h}$. Tissues were dehydrated stepwise in alcohol solution series, then in toluene. After their embedding in paraffin the samples were stained with hematoxylin, safranin and aniline blue. The observations, which covered at least five samples taken from control or treated plants, were performed using a light microscope (Leica RM2165) equipped with a micrometric rule. The micrographs were digitized with a scanner (HP Scanjet 3800, Hewlett Packard, USA) and analysed with a software (ImageJ, National Institutes of Health Bethesda, MD), to measure mesophyll thickness and vascular bundle diameter of leaves. A minimum of three samples were examined per each treatment.

\section{Statistical analysis}

Statistical analysis was performed with Statistica ${ }^{\mathrm{TM}}$ software, using ANOVA and mean comparison with Duncan's test. Values were calculated at the $p \leq 0.05$ probability level. 


\section{RESULTS}

\section{Effect of salt treatment on germination}

All germination curves reached a plateau (FG\%max : maximum $\mathrm{FG} \%$ ), but they differed on the value of $\mathrm{FG} \% \max$ and on the time necessary to reach this value (Fig. 1). For M. scutellata seeds, FG\%max exceeded $80 \%$ at 0 and $86 \mathrm{mM} \mathrm{NaCl}$, but it was reduced to $60 \%$ at $170 \mathrm{mM} \mathrm{NaCl}$. Furthermore, the latency for radicle emergence augmented with salt concentration. Embryonic axis biomass was more affected by salt than cotyledons (Table 1). At $170 \mathrm{mM} \mathrm{NaCl}$, embryonic axis biomass was restricted by $66 \%$ as compared with control (no salt), whereas cotyledon biomass was restricted only by $20 \%$. Embryonic axis length was still more sensitive to salt inhibition: Embryonic axis length was diminished by $35 \%$ at $86 \mathrm{mM} \mathrm{NaCl}$ and by $76 \%$ at $170 \mathrm{mM} \mathrm{NaCl}$. In embryonic axis and cotyledon, salt limited water content (Table 1).

Table 1

Effect of different $\mathrm{NaCl}$ concentrations $(0,86$ and $170 \mathrm{mM})$ on length, water content and dry weight in embryonic axis and cotyledons of M. scutellata. Seeds were germinated on moist filter paper for $9 \mathrm{~d}$ in the absence (control) or in the presence of $\mathrm{NaCl}$. Data are the means of three replicates \pm confidence interval. Means sharing a same letter are not significantly different at $p=0.05$ (ANOVA and mean comparison with Duncan's test)

\begin{tabular}{|c|c|c|c|c|c|}
\hline \multirow{2}{*}{$\mathrm{NaCl}, \mathrm{mM}$} & \multicolumn{3}{|c|}{ Embryonic axis } & \multicolumn{2}{c|}{ Cotyledons } \\
\cline { 2 - 6 } & Length $(\mathrm{cm})$ & $\begin{array}{c}\text { Water content } \\
\left(\mathrm{mL} \cdot \mathrm{g}^{-1} \mathrm{DW}\right)\end{array}$ & Dry weight $(\mathrm{g})$ & $\begin{array}{c}\text { Water content } \\
\left(\mathrm{mL}^{-1} \mathrm{gW}\right)\end{array}$ & Dry weight $(\mathrm{g})$ \\
\hline 0 & $14.33 \pm 0.87^{\mathrm{a}}$ & $23.02 \pm 2.27^{\mathrm{a}}$ & $0.142 \pm 0.08^{\mathrm{a}}$ & $7.07 \pm 2.03^{\mathrm{a}}$ & $0.211 \pm 0.00^{\mathrm{a}}$ \\
\hline 86 & $9.28 \pm 0.97^{\mathrm{b}}$ & $16.03 \pm 2.06^{\mathrm{b}}$ & $0.077 \pm 0.00^{\mathrm{b}}$ & $4.20 \pm 0.24^{\mathrm{b}}$ & $0.173 \pm 0.01^{\mathrm{b}}$ \\
\hline 170 & $3.5 \pm 0.33^{\mathrm{c}}$ & $11.79 \pm 1.74^{\mathrm{c}}$ & $0.048 \pm 0.00^{\mathrm{c}}$ & $3.01 \pm 0.58^{\mathrm{b}}$ & $0.168 \pm 0.00$ \\
\hline
\end{tabular}

Data are the mean of three samples of 25 seedlings each one of treatment.
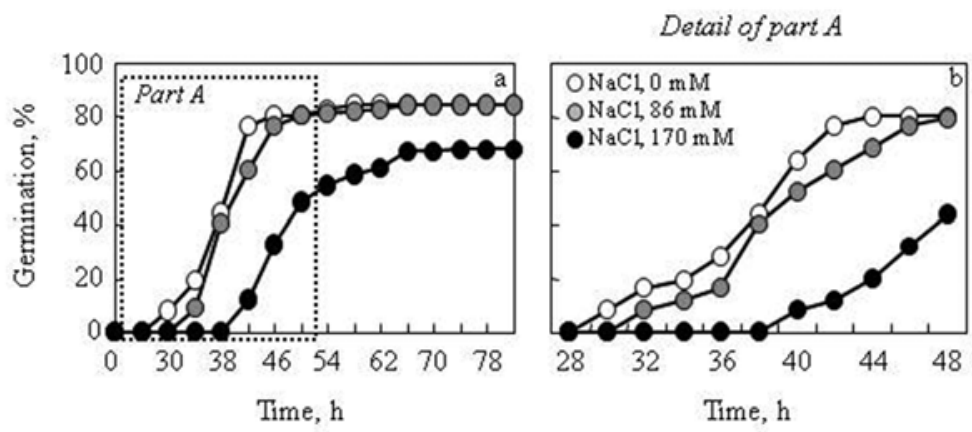

Fig. 1. Effect of different $\mathrm{NaCl}$ concentrations $(0,86$ and $170 \mathrm{mM})$ on germination percentage of M. scutellata after 9 days of treatment 


\section{Effect of salt treatment on plant growth, water content and ion accumulation}

Control plants displayed a total dry weight of about $217 \mathrm{mg}$. This biomass was distributed as follows: $52 \%$ in leaves, $31 \%$ in stems, and $17 \%$ in roots (Fig. 2A). Salt treatment significally decreased $M$. scutellata growth for the different organs: roots, stems and leaves at both, low $(86 \mathrm{mM})$ and high $(170 \mathrm{mM}) \mathrm{NaCl}$ concentrations For leaves, the decrease in biomass under salinity was due to a gradual reduction in whole area (Table 2). Moreover, water content was drastically reduced by salt concentration, the most pronounced effect was observed in leaves $(-69 \%$ of control) and to a lower degree in roots ( $-44 \%$ of control) at $\mathrm{NaCl} 170 \mathrm{mM}$ (Fig. 2B).

Medicago scutellata plants cultivated under increasing salinity showed a significantly higher $\mathrm{Na}^{+}$accumulation in leaves and roots, as compared to stems (Fig. 2C). At high salinity concentration $(\mathrm{NaCl} 170 \mathrm{mM})$ a main amount of $\mathrm{Na}^{+}$content was more accumulated in roots and leaves than in stems, suggesting that M. scutellata was able to adopt an includer strategy. On the other hand, salt treatment induced a significant decrease of $\mathrm{K}^{+}$content in roots and stems (Fig. 2D). Potassium content in leaves was not affected by salt. These results suggested that $\mathrm{K}^{+}$was more allocated in leaves than stems and roots in the presence of salt.
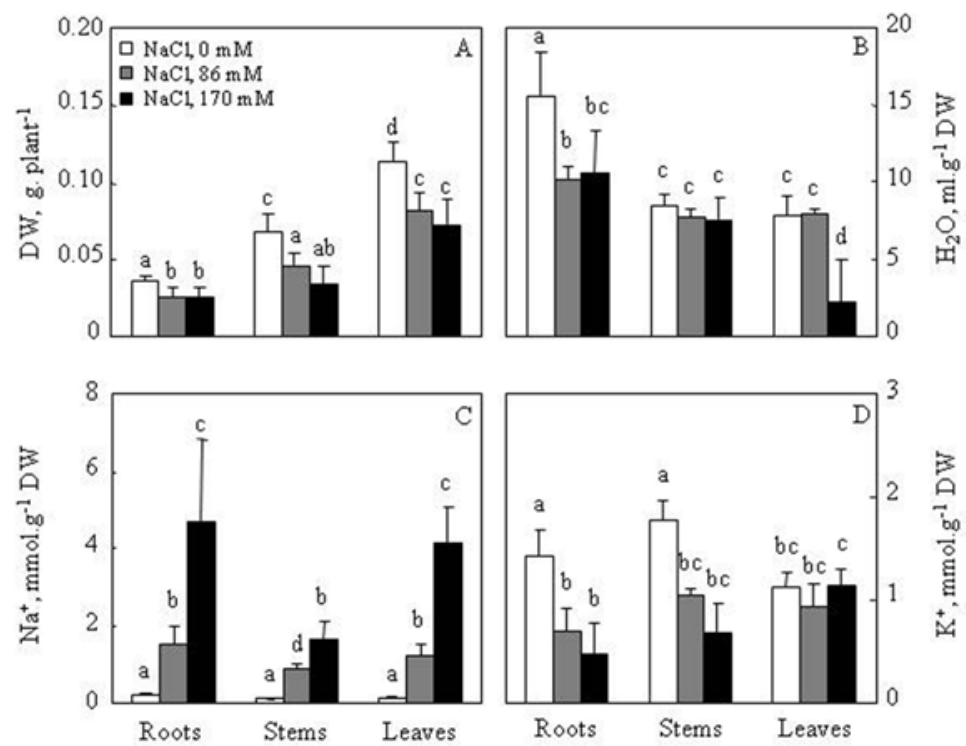

Fig. 2. Effect of different $\mathrm{NaCl}$ concentrations $(0,86$ and $170 \mathrm{mM})$ on organ biomass (A), water content (B), sodium content (C) and potassium (D) content of M. scutellata. Twenty-eight-day-old plants were grown for 7 days in the absence (control) or in the presence of $\mathrm{NaCl}$. Data are the means of five replicates \pm confidence interval. Means labeled with the same letter are not significantly different at $p=0.05$ (ANOVA and mean comparison with Duncan's test) 
Table 2

Effect of different $\mathrm{NaCl}$ concentrations on stem length, root length, total leaf area, number of stem shoots and on mesophyll thickness and vascular bundle diameter number of leaf of M. scutellata. Twenty-eightday-old plants were grown for 7 days in the absence (control) or in the presence of $\mathrm{NaCl}$. Stars indicate significant differences between control and treatments

\begin{tabular}{|l|c|c|c|}
\hline \multirow{2}{*}{\multicolumn{1}{|c|}{ Parameters }} & \multicolumn{3}{c|}{ Treatment $(\mathrm{NaCl}, \mathrm{mM})$} \\
\cline { 2 - 4 } & 0 & 86 & 170 \\
\hline Stem length, cm & $16 \pm 1.0$ & $13 \pm 0.9^{*}$ & $11 \pm 1.0^{*}$ \\
\hline Root length, cm & $32 \pm 7.0$ & $26 \pm 5.0$ & $25 \pm 4.0$ \\
\hline Total leaf area, $\mathrm{cm}^{2} \cdot$ plant $^{-1}$ & $7 \pm 0.6$ & $5 \pm 0.7^{*}$ & $4 \pm 0.3^{*}$ \\
\hline Number of stem shoots & $7 \pm 1.0$ & $6 \pm 0.0$ & $5 \pm 0.0$ \\
\hline Mesophyll thickness, $\mu \mathrm{m}$ & 6.117 & - & $5.072^{*}$ \\
\hline Vascular bundle diameter, $\mu \mathrm{m}$ & 4.772 & - & $3.549^{*}$ \\
\hline
\end{tabular}

Data are the means of five replicates \pm confidence interval $(p=0.05)$

\section{Effect of salt treatment on chlorophyll content}

Salt treatment induced a large decrease in the chlorophyll of $M$. scutellata leaves (Fig. 3). The reduction was similar at both 86 and $170 \mathrm{mM} \mathrm{NaCl}$. At high salinity, Chl $\mathrm{a}$ and $\mathrm{Chl} \mathrm{b}$ contents diminished by $77 \%$ and $83 \%$, respectively, in comparison to the control (Fig. 3).

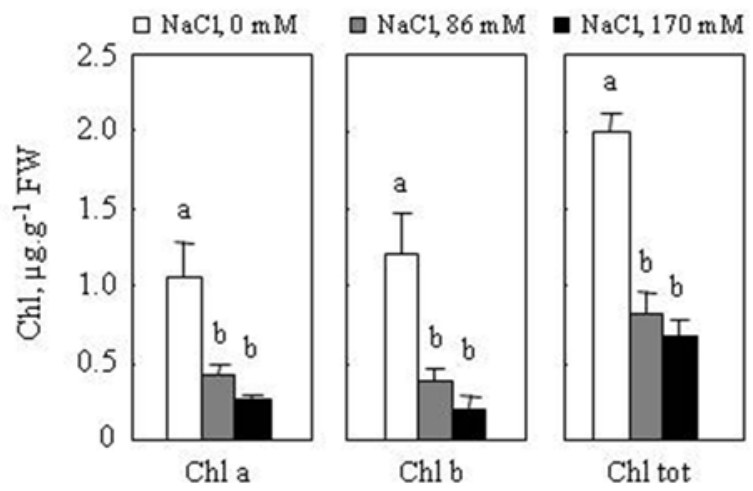

Fig. 3. Effect of different $\mathrm{NaCl}$ concentrations $(0,86$ and $170 \mathrm{mM})$ on chlorophyll contents of M. scutellata. Plants were grown and harvested as described in the legend of Fig. 2. Data are the means of four replicates \pm confidence interval. Means sharing labeled with the same letter are not significantly different at $p=0.05$ (ANOVA and mean comparison with Duncan's test) 


\section{Effect of salt treatment on membrane permeability}

The extent of membrane damage was estimated by electrolyte leakage and MDA level in root and leaf tissues. These parameters increased by salt in both organs (Fig. 4). In roots and leaves, electrolyte leakage progressively were increased with $\mathrm{NaCl}$ concentration (Fig. 4A). In addition, increased MDA content in roots and leaves of $M$. scutellata indicated that the application of $\mathrm{NaCl}$ resulted in enhanced lipid peroxidation (Fig. 4B).
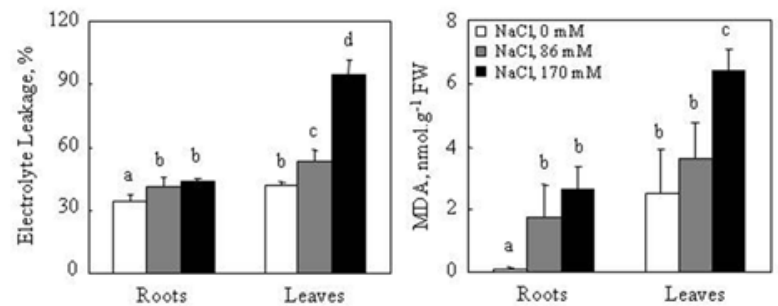

Fig. 4. Effect of different $\mathrm{NaCl}$ concentrations $(0,86$ and $170 \mathrm{mM})$ on: electrolyte leakage and MDA content of M. scutellata. Plants were grown and harvested as described in the legend of Fig. 2. Data are the means of six replicates \pm confidence interval. Means sharing labeled with the same letter are not significantly different at $p=0.05$ (ANOVA and mean comparison with Duncan's test)

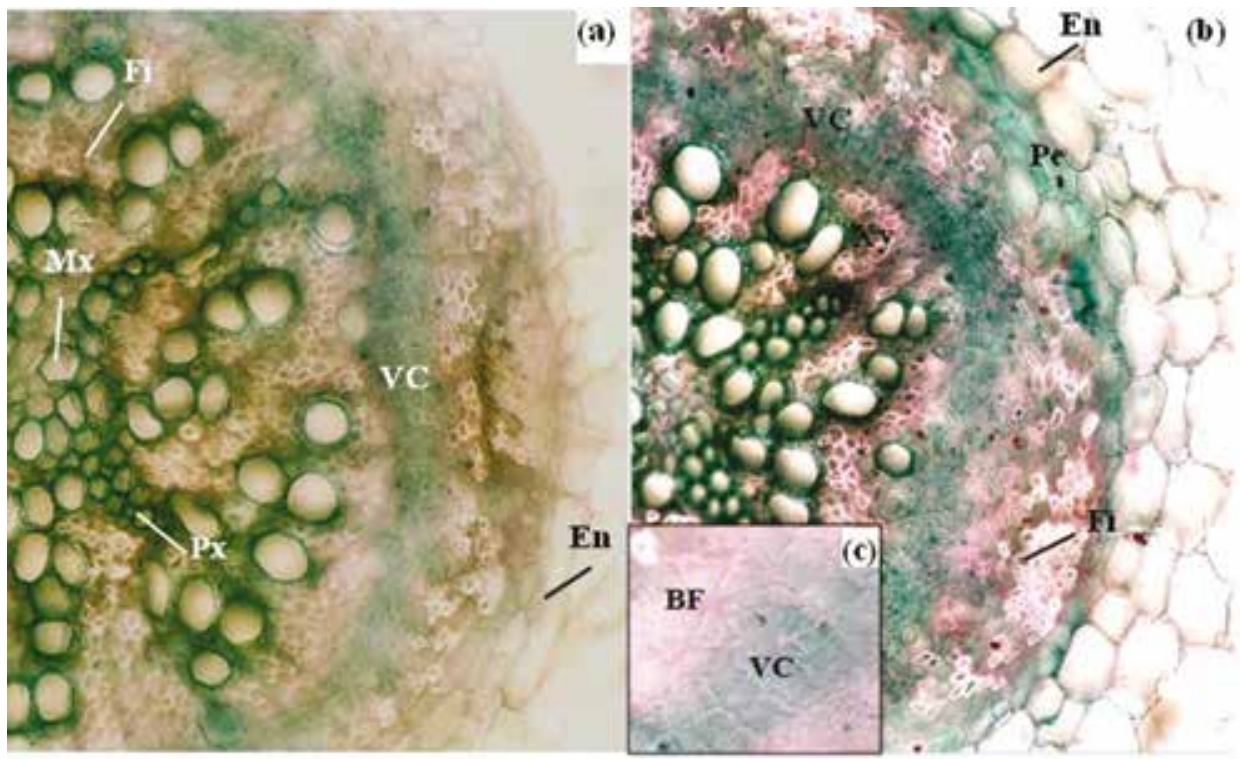

Fig. 5. Light micrographs showing root cross-sections of $M$. scutellata. Twenty-eight-day-old plants were grown for 7 days in the absence (a) or in the presence of $\mathrm{NaCl} 170 \mathrm{mM}$ (b). (c) detail of (b) at the cambial zone. Roots were sectioned $2.5 \mathrm{~cm}$ from root-stem junction and stained using a mixture of alum carmine and methyl-green. Alum carmine was applied to reveal a cellulose cell wall component of phloem and methyl-green to reveal lignified and suberin in the cell walls. Enlargement $\times 400$. Abbreviations: $\mathrm{BF}$ - bast fibers; En - endodermis; Fi - fibers; Mx - metaxylem; Pe - pericycle; $\mathrm{Px}$ protoxylem; VC - Vascular Cambium; Xy - xylem 

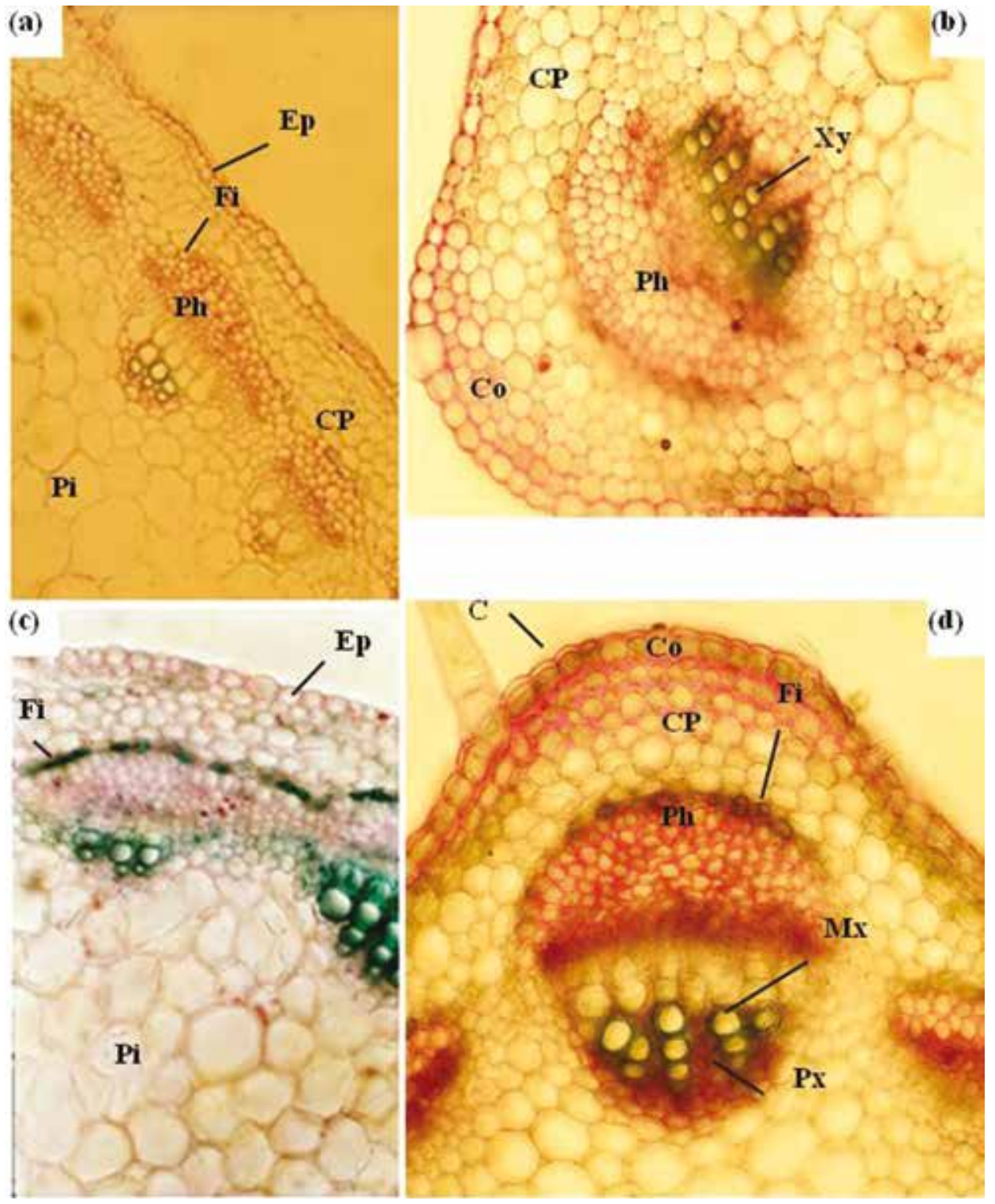

Fig. 6. Transverse sections of M. scutellata stems. Twenty-eight-day-old plants were grown for 7 days in the absence ( $a$ and $b$ ) or in the presence of $170 \mathrm{mM} \mathrm{NaCl}$ ( $c$ and d). Stems were sectioned at the fourth internode and stained using a mixture of alum carmine and methyl-green. Alum carmine was applied to reveal a cellulose cell wall component of phloem and methyl-green to reveal lignin and suberin contents of the cell walls. $b$ detail of a; d detail of c. Enlargement: $\times 150$ (a and c), $\times 200$ ( $b$ and d). Abbreviations: $\mathrm{C}$ - cuticle; Co - collenchyma; $\mathrm{CP}$ - cortical parenchyma; Ep - epidermis; $\mathrm{Fi}$ - fibers; $\mathrm{Mx}$ - metaxylem; $\mathrm{Ph}$ - phloem; Pi - pith; Px - protoxylem; Xy - xylem 


\section{Histological observations}

Under $\mathrm{NaCl}$ stress $(170 \mathrm{mM})$, reduction of root diameter was attributed to restricted central cylinder area $(9.8,3.6$ and 3.8, for control plants and 7.1, 2.7 and 2.3 for treated plants, respectively, in root diameter, central cylinder diameter and thickness of cortex [mm]). Morphometric analyses (results not shown) confirm that $\mathrm{NaCl}$ increased the number of sclerenchyma fibers (Fi). Salt induced also a reduction in the number of tracheary elements, significant increase in lignified fibrous layer (Fi) and bast fiber (BF); at the cambial zone, it causes a significant lignification (Fig. 5).

After 7 days of $\mathrm{NaCl}$ treatment $(170 \mathrm{mM})$, the stem diameter remained unchanged, however, the central cylinder exhibited a high lignification process ( $\mathrm{Fi}$ ) concomitantly with an increase in xylem number (Fig. 6). In the central cylinder of root sections, it appeared clearly that the cell walls are much thicker and the pinkish colour is much more intense in the salt-treated than they were in the control seedlings, which is again consistent with an increased process of lignification under saline conditions (Fig. 6).

\section{DISCUSSION}

Soil salinity is a prevalent abiotic stress for plants, with retarded growth being a common response to salinity. Plant growth is one of the most important agricultural indices of salt stress tolerance [27]. Salt stress can induce both a reduction in seed germination and a delay in the initial germination process in glycophytes and to a lesser extent in halophytes [11]. The increase in salinity does not only decrease germination, but also delays the initial germination rate [26]. In our present study, the latency for radicle emergence augmented with salt concentration, notably under $170 \mathrm{mM} \mathrm{NaCl}$ in M. scutellata seeds. It was hypothesized that the presence of $\mathrm{NaCl}$, even at low concentrations, could contribute to a decrease in the internal osmotic potential of germinating structures [18]. At $170 \mathrm{mM} \mathrm{NaCl}$ treatment, a significant decrease in the germination percentage of $M$. scutellata was observed. Embryonic axis exhibited high reduction of DW and water content as compared to cotyledon especially at this concentration of NaCl. This might be due to toxic effects of $\mathrm{Na}^{+}$and/or $\mathrm{Cl}^{-}$in seed tissues as well as unbalanced nutrient uptake induced by salt. Toxic accumulation of salt in leaf cell cytoplasm is prevented by two strategies: by salt exclusion from leaves, or by efficient ion compartmentalization in vacuoles of include leaves. The excluder strategy is poorly efficient when soil salinity is high, and thus it is found only in salt-sensitive glycophytes. On the contrary, salt inclusion is typical of salt-tolerant glycophyte and halophytes. However, even in includers, $\mathrm{Na}^{+}$transport to shoot is strictly controlled, and the efficiency of this control is related to salt tolerance [13].

In the present study, the application of $\mathrm{NaCl}(86$ and $170 \mathrm{mM})$ in the hydroponic media caused a remarkable reduction in DW of the shoot (leaves and stems), and no salt effect was visible on roots. At this point, it seems that shoot was more sensitive to salt stress than root. These results are in good accordance with those reported by 
da Silva et al. [8] who found that leaves and stems are more sensitive to salt stress than roots in Spondias tuberosa. In Pea, it has been shown that the application of 50 $\mathrm{mM} \mathrm{NaCl}$ resulted in a drastic decrease in leaf growth [4]. Salt stress also reduced total leaf area of M. scutellata. These effects could be related to an inhibition of new leaf initiation and/or reduction of leaf expansion [5]. Our results also demonstrate a decrease of water content in roots and leaves (at $170 \mathrm{mM} \mathrm{NaCl}$ ). In spite of the high concentration of $\mathrm{NaCl}$, the stem hydration was maintained at the same value as in control plants. At $170 \mathrm{mM} \mathrm{NaCl}, \mathrm{Na}^{+}$accumulation is more important in roots and leaves than in stems. High $\mathrm{Na}^{+}$content in roots and stems were associated with $\mathrm{K}^{+}$ limitation. These results, which are in agreement with those found in A. thaliana [3], $M$. sativa [23], and T. ammi [1], suggest that $\mathrm{K}^{+}$is one of the most growth-limiting factors in M. scutellata under saline conditions.

Sensitivity of $M$. scutellata leaves to salt stress was probably due to an osmotic effect, as leaf tissue hydration was severely affected despite their high $\mathrm{Na}^{+}$concentrations. However, some of these ions were accumulated in cytoplasm. According to Wenxue et al. [34], high $\mathrm{Na}^{+}$concentrations were not associated with limitation of essential nutrient uptake like $\mathrm{K}^{+}$and $\mathrm{Ca}^{2+}$, which were allocated to shoots.

When plants were grown in salty medium, chlorophyll concentration was largely diminished in M. scutellata. The loss of chlorophylls is considered as a marker of salt stress [5]. Thus, our results support the hypothesis that chloroplasts were severely altered by salt as well as leaf cell membrane, as attested by the magnitude of electrolyte leakage. There is increasing evidence that membrane injury under salt stress is related to a higher production of toxic ROS [24]. Determining the MDA concentration and hence, the extent of membrane lipid peroxidation, has often been used as a tool to assess the severity of oxidative stress [6]. Our data showed that, after seven days of $\mathrm{NaCl}$ treatment, membrane lipid peroxidation was induced and MDA contents in leaves and roots were much higher as compared to control. Our results are in agreement with those of Sairam and Srivastava [31], who reported enhanced concentration of MDA in salt-sensitive rice cultivar as compared to the tolerant cultivar, and in Lemna minor roots.

All results discussed above, demonstrate the effects of salt stress on some physiological and biochemical parameters in M. scutellata. This type of stress can also cause structural changes in plant organs. In Rangpur lime $(C$. limonia) and Etrog citron $(C$. medica) grown in the presence of $100 \mathrm{mM} \mathrm{NaCl}$, the hypodermal cells developed lignified and suberized walls which blocked the plasmodesmata and resulted in degeneration of the cell contents [33]. According to these authors, the primary endodermal cells had lignified Casparian strips and plasmodesmata in other cell wall areas. These connections were blocked by secondary suberization except the endodermal passage cells opposite to protoxylem arcs. Zhong and Läuchli [35] have shown that $150 \mathrm{mM} \mathrm{NaCl}$ increased significantly cell wall uronic acid content in cotton seedlings, but reduced cellulose content on a per unit dry weight basis. These results reveal a relationship between the effects of high salinity on root growth and cell wall metabolism, particularly in regard to cellulose biosynthesis. In G. hirsutum, $\mathrm{NaCl} 200 \mathrm{mM}$ induced the formation of an exodermis with Casparian bands and 
suberin lamellae close to the root base and in the transition zone to hypocotyl. The exodermis, which is absent in control roots, may play a role in protecting the root from water loss and/or leakage of solutes important for osmotic adjustment [29].

Contrary to the plants species mentioned previously, an increase of the number of wood fiber, bast fiber (which cover the liber) and suberization of the cambial zone was reported in $M$. scutellata. This phenomenon stiffens the organ and consequently decreases its growth. It may nevertheless be protected, at least in part against loss of water. In M. scutellata, the suberization of the cambium stiffens also the cell walls, reducing their elasticity and plasticity, and blocking the formation of secondary vascular elements (phloem and xylem) which contribute to exchange limitation and growth inhibition.

Besides suberization of tissues, $M$. scutellata reacts to salt by reducing mesophyll cell size and spongy parenchyma gaps which causes a narrowing of all cells and consequently a decrease in intercellular spaces and leaf thickness. This phenomenon causing a decrease in the rate of $\mathrm{CO}_{2}$ at the foliar parenchyma would lead to a disruption of photosynthetic activities. Such a reduction was observed in other species under the effect of other types of stress. In bean, salinity caused a reduction in both mesophyll and epidermal cells [2]. In cucumber plants the salt stressed leaves had shorter palisade cells but the spongy mesophyll was thicker and had less air spaces compared to control plants [21]. Contrally, salinity significantly reduced the crosssectional area, width, and radii of both epidermal and mesophyll cells along the leaf axis in wheat. The reduction was attributed to a decrease in the size and number of medium and small veins [17]. Reinoso et al. [30] showed that salinity induced anatomical changes in roots (young and mature zones) of Prosopis strombulifera. The diameters of the young zone of roots of plants grown in increasing salt concentrations were smaller than those of controls, with reduced number of cortex layers and reduced size of the vascular system. The roots from tolerant plants showed precocious suberization and (or) lignification of the endodermal cells and early activity of the pericycle. The stem diameter of young tolerant plants was notably diminished and less tissue lignification occurred. According to literature data, some water-soluble peroxidases have been hypothesised to have auxin oxidase activity (which might explain the effect observed on the root biomass), while the cell-wall peroxidases would be involved in lignification. Histochemical observation confirmed a more intense lignification in the root cells of the salt-tolerant species compared to the sensitive species in wheat seedlings, under the effect of $\mathrm{NaCl}$ [19].

All these anatomical changes, including the phenomenon of suberization and lignification refers to an early differentiation in tissues under saline conditions.

In conclusion, our results demonstrate that salinity inhibited germination and early seedling growth in M. scutellata. Content of $\mathrm{Na}^{+}$in roots and leaves were higher than those in stems. Accumulation of $\mathrm{Na}^{+}$resulted in a decrease of plant biomass, and chlorophyll content which presumably limited photosynthetic activity. Furthermore, salt induced membrane damages in both roots and leaves. Anatomical observations indicated a more intense suberization and lignification at the cambial zone of roots of M. scutellata under the effect of $\mathrm{NaCl}$. 


\section{REFERENCES}

1. Ashraf, M., Orooj, A. (2006) Salt stress effects on growth, ion accumulation and seed oil concentration in an arid zone traditional medicinal plant ajwain (Trachyspermum ammi [L.] Sprague). J. Arid. Environ. 64, 209-220.

2. Asish, K. P., Anath, B. D. (2004) Salt tolerance and salinity effects on plants. Ecotox. Environ. Safe. 60, 324-349.

3. Attia, H., Karray, N., Rabhi, M., Lachaâl, M. (2008) Salt-imposed restrictions on the uptake of macroelements by roots of Arabidopsis thaliana. Acta Physiol. Plant. 30, 723-727.

4. Attia, H., Nouaili, S., Soltani, A., Lachaâl, M. (2009) Comparison of the responses to NaCl stress of two pea cultivars using split-root system. Sci. Hort. 123, 164-169.

5. Attia, H., Ouhibi, C., Ellili, A., Msilini, N., Bouzaïen, G., Karray, N., Lachaâl, M. (2011) Analysis of salinity effects on basil leaf surface area, photosynthetic activity, and growth. Acta Physiol. Plant. 33, 823-833.

6. Ben Amor, N., Hamed, K. B., Debez, A., Grignon, C., Abdelly, C. (2005) Physiological and antioxidant responses of the perennial halophyte Crithmum maritimum to salinity. Plant Sci. 168, 889-899.

7. Chinnusamy, V., Jagendorf, A., Zhu, J. K. (2005) Understanding and improving salt tolerance in plants. Crop Sci. 45, 437-448.

8. da Silva, E. C., Nogueira, R. J. M. C., Araujo, F. P., Melo, N. F., de Azevedo Neto, A. D. (2008) Physiological responses to salt stress in young umbu plants. Environ. Exp. Bot. 63, 147-157.

9. Dionisio-Sese, M. L., Tobita, S. (1998) Antioxidant responses of rice seedlings to salinity stress. Plant Sci. 135, 1-9.

10. Duzan, H. M., Zhou, X., Souleimanov, A., Smith, D. L. (2004) Perception of Bradyrhizobium japonicum Nod factor by soybean [Glycine max (L.) Merr.] root hairs under abiotic stress conditions. J. Exp. Bot. 55, 2641-2646.

11. El-Keblawy, A. (2004) Salinity effects on seed germination of the common desert range grass, Panicum turgidum. Seed Sci. Technol. 32, 943-948.

12. Fakhari, F., Sadeghi, H. (2016) Investigating the effects of pod elimination on salinity tolerance in annual Medic (Medicago scutellata L.). J. Rangeland Sci. 6, 232-241.

13. Garthwaite A. J., Millhollon, E. P., Lucas, M. C. (2005) Salt tolerance in wild Hordeum species is associated with restricted entry of $\mathrm{Na}^{+}$and $\mathrm{Cl}^{-}$into the shoots. J. Exp. Bot. 56, 2365-2378.

14. Graham, P. H., Vance, C. P. (2003) Legumes: importance and constraints to greater use. Plant Physiol. 131, 872-877.

15. Heath, R. L., Packer, L. (1968) Photooxidation in isolated chloroplasts I: kinetics and stoichiometry of fatty acid peroxidation. Arch. Biochem. Biophys. 125, 189-198.

16. Hoagland, D. R., Arnon, D. I. (1950) The water culture method for growing plants without soil. Circ 347. Cal. Agri. Exp. Stat. Berkley.

17. Hu, Y., Fricke, W., Schmidhalter, U. (2005) Salinity and the growth of non-halophytic grass leaves: the role of mineral nutrient distribution. Funct. Plant Biol. 32, 973-985.

18. Huang, W. L., Liu, F. L. (2002) Carbohydrate metabolism in rice during callus induction and shoot regeneration induced by osmotic stress. Bot. Bull. Acad. Sinica 43, 107-113.

19. Jbir, N., Chaïbi, W., Ammar, S., Jemmali, A., Ayadi, A. (2001) Root growth and lignification of two wheat species differing in their sensitivity to $\mathrm{NaCl}$, in response to salt stress. C.R. Acad. Sci. Paris, Sciences de la vie / Life Sciences 324, 863-868.

20. Lazrek, F., Roussel, V., Ronfort, J., Cardinet, G., Chardon, F., Aouani, M. E., Huguet, T. (2009) The use of neutral and non-neutral SSRs to analyse the genetic structure of a Tunisian collection of Medicago truncatula lines and to reveal associations with eco-environmental variables. Genetica 135, 391-402.

21. Lechno, S., Zamski, E., Telor, E. (1997) Salt stress-induced responses in cucumber plants. J. Plant Physiol. 150, 206-211.

22. McKinney, G. (1941) Absorption of light by chlorophyll solutions. J. Biol. Chem. 140, 315-332. 
23. Mezni, M., Albouchi, A., Bizid, E., Hamza, M. (2002) Effet de la salinité des eaux d'irrigation sur la nutrition minérale chez trois variétés de Luzerne pérenne (Medicago sativa). Agronomie 22, 283-291.

24. Mittler, R. (2002) Oxidative stress, antioxidants and stress tolerance. Trends Plant Sci. 7, 406-410.

25. Mtimet, A. (2001) Soils of Tunisia. In: Zdruli, P., Steduto, P., Lacirignola, C., Montanarella, L. (eds) Soil resources of southern and eastern mediterranean countries. Bari, Italy, pp. 243-262.

26. Nasri, N., Kaddour, R., Rabhi, M., Plassard, C., Lachaâl, M. (2011) Effect of salinity on germination, phytase activity and phytate content in lettuce seedling. Acta Physiol. Plant. 33, 935-942.

27. Parida, A. K., Das, A. B. (2005) Salt tolerance and salinity effects on plants. Ecotox. Environ. Safe. 60, 324-349.

28. Piano, E., Francis, C. M. (1992) The annual species of Medicago in the Mediterranean region: ecogeography and related aspects of plant introduction and breeding. In: Proceedings of the 10th International Conference of Eucarpia Medicago spp. (Group Lodi), Italy, pp. 373-385.

29. Reinhards, D. H., Rost, T. L. (1995) Salinity accelerates endodermal development and induces an exodermis in cotton seedling roots. Environ. Exp. Bot. 35, 563-574.

30. Reinoso, H., Sosa, L., Ramírez, L., Luna, V. (2004) Salt-induced changes in the vegetative anatomy of Prosopis strombulifera (Leguminosae). Rev. Can. Bot. 82, 618-628.

31. Sairam, R. K., Srivastava, G. C. (2002) Changes in antioxidant activity in sub-cellular fractions of tolerant and susceptible wheat genotypes in response to long term salt stress. Plant Sci. 162, 897-904.

32. Shalata, A., Neumann, P. M. (2001) Exogenous ascorbic acid (vitamin C) increases resistance to salt stress and reduces lipid peroxidation. J. Exp. Bot. 52, 2207-2211.

33. Walker, R. R., Sedgley, M., Blesing, M. A., Douglas, T. J. (1984) Anatomy, ultrastructure and assimilate concentrations of roots of citrus genotypes differing in ability for salt exclusion. J. Exp. Bot. 35, 1481-1494.

34. Wenxue, W., Bilsborrow, P. E., Hooley, P., Fincham, D. A., Lombi, E., Forster, B. P. (2003) Salinity induced differences in growth, ion distribution and partitioning in barley between the cultivar Maythorpe and its derived mutant Golden Promise. Plant Soil 250, 183-191.

35. Zhong, H., Läuchli, A. (1993) Changes of cell wall composition and polymer size in primary roots of cotton seedlings under salt stress. J. Exp. Bot. 44, 773-778. 